\title{
EVALUATION OF PROCALCITONIN AS A MARKER IN THE DIAGNOSIS OF NEONATAL SEPSIS
}

\author{
Gayathri $P^{1}$, Umasudhan $B^{2}$, Ashok $S^{3}$, Radhika A. R', Vanitha $M^{5}$ \\ ${ }^{1}$ Senior Assistant Professor, Department of Pathology, Government Vellore Medical College, Vellore. \\ ${ }_{2}^{2}$ MBBS Student, Government Vellore Medical College, Vellore. \\ ${ }^{3}$ Professor and HOD, Department of Pathology, Government Vellore Medical College, Vellore. \\ ${ }^{4}$ Associate Professor, Department of Pathology, Government Vellore Medical College, Vellore. \\ 5Tutor, Department of Pathology, Government Vellore Medical College, Vellore.
}

ABSTRACT

\section{BACKGROUND}

To estimate the level of procalcitonin in neonatal sepsis and to compare the sensitivity and specificity of procalcitonin with that of WBC count, immature to total neutrophil ratio, CRP level and blood cultures.

\section{MATERIALS AND METHODS}

This study was conducted on neonates admitted to the Neonatal Intensive Care Unit, GVMCH, Vellore, Tamilnadu with a clinical diagnosis of neonatal sepsis over a period of 8 months, July 2015 to February 2016. Before commencing anti-microbial therapy, blood samples were collected from 50 neonates who were clinically diagnosed as sepsis and subjected to sepsis workup, which includes complete blood count, immature to total neutrophil ratio (I/T ratio), CRP, blood culture and procalcitonin levels. CRP levels were semi-quantitatively assessed by Rapid Latex agglutination slide method (Mediclone Biotech) and the cut-off value was $6 \mathrm{mg} / \mathrm{dL}$. Procalcitonin was assessed by the Human Procalcitonin ELISA kit. (Sincere Biotech) and the readings were read in Biorad microplate reader. Data were expressed as sensitivity, specificity and statistical significance was assessed by Chi-Square test.

\section{RESULTS}

Out of 50 neonates CRP level was increased in 26 neonates, 14 in proven sepsis group, 8 in suspected sepsis group and 4 in clinical sepsis group. Procalcitonin level was increased in 12 neonates out of 50, 8 in proven sepsis and 4 in clinical sepsis. The sensitivity of procalcitonin was $36.36 \%$ and the specificity was $85.71 \%$.

\section{CONCLUSION}

The low sensitivity of procalcitonin can be attributed to the small sample size and may be due to perinatal factors, so this level should be correlated with clinical findings, CRP level and blood culture.

\section{KEYWORDS}

Neonatal Sepsis, Procalcitonin, CRP, Blood Culture, I/T Ratio.

HOW TO CITE THIS ARTICLE: Gayathri P, Umasudhan B, Ashok S, et al. Evaluation of procalcitonin as a marker in the diagnosis of neonatal sepsis. J. Evolution Med. Dent. Sci. 2017;6(27):2247-2250, DOI: 10.14260/Jemds/2017/484

\section{BACKGROUND}

Neonatal sepsis is a serious disease and it is one of the leading cause of mortality in neonatal period.[1] It affects 1 - 4 in 1000 babies in developed countries.[2] In India the incidence varies from 11 - 24.5/1000 live births.[3] Since the clinical signs and symptoms of sepsis are vague, with high mortality and morbidity we are in a situation to commence antibiotics before the result of blood culture. Although the gold standard blood culture can be negative in infective neonates due to prior use of antibiotics, sampling issues or poor laboratory resources ${ }^{[4]}$ and the result will be ready only after $24-72$ hours of sampling and during this period we have to treat the neonates.

Haematologic investigations, viz. total WBC count and neutrophil count, lymphocyte count can be used, but these

Financial or Other, Competing Interest: None.

Submission 24-02-2017, Peer Review 20-03-2017,

Acceptance 27-03-2017, Published 03-04-2017.

Corresponding Author:

Dr. Gayathri $P$,

Senior Assistant Professor,

Department of Pathology,

Government Vellore Medical College,

Vellore.

E-mail: gaibaski@gmail.com

DOI: $10.14260 /$ jemds $/ 2017 / 484$

\section{(c) $($ ) $(-)$}

values varies with gestation, postnatal age and can be confused by machines including nucleated RBC'S.[5] Furthermore, the WBC count is raised in many non-infective condition such as periventricular haemorrhages, convulsion and hypoxic ischaemic encephalopathy. ${ }^{[5]}$

Immature to total neutrophil ratio and absolute neutrophil counts have higher specificity, but are often normal early in the course of infection.[4]

C-reactive protein as acute phase reactants does not reliably differentiate between the systemic inflammatory response and the sepsis.[6] Therefore, in the current scenario identifying a biomarker with higher sensitivity, specificity and diagnosing the infection earlier would be beneficial.

\section{MATERIALS AND METHODS}

This study aim to estimate the level of procalcitonin in neonatal sepsis and to compare the sensitivity and specificity of procalcitonin with that of WBC count, immature to total neutrophil ratio, CRP level and blood cultures.

This prospective study was conducted on neonates admitted to the neonatal intensive care unit GVMCH, Vellore, Tamilnadu with a clinical diagnosis of neonatal sepsis over a period of 8 months July 2015 to February 2016.

This study was approved by the Institutional Scientific Ethical Committee and informed consent was obtained from parents. Neonates with clinical diagnosis of sepsis were 
included in this study. Neonates who had antibiotics with history of birth asphyxia, congenital anomalies, laboratory studies suggestive of inborn error of metabolism were excluded from this study.

Before starting antimicrobial therapy, blood samples were collected from 50 neonates who were clinically diagnosed as sepsis and subjected to sepsis workup which includes complete blood count, Immature to total neutrophil ratio (I/T Ratio), CRP, blood culture and procalcitonin levels. WBC count of more than 18,000 cells/cu.mm and I/T ratio of $>0.2$ were considered as abnormal in this study.

CRP levels were semi-quantitatively assessed by rapid latex agglutination slide method (Mediclone Biotech) and the cut-off value was $6 \mathrm{mg} / \mathrm{dL}$.

Procalcitonin was assessed by the Human Procalcitonin ELISA kit. (Sincere Biotech) and the readings were read in Biorad microplate reader.

Levels more than $2000 \mathrm{pg} / \mathrm{mL}$ were taken as positive.

Data were expressed as sensitivity, specificity and statistical significance was assessed by Chi-Square test.

Depending upon the results, neonates were classified into three groups (Table 1).[7]

\section{RESULTS}

50 Neonates were analysed. Out of these 50, 22 had proven sepsis, 8 neonates grouped under suspected sepsis and 20 neonates grouped under clinical sepsis. All the neonates in our study are less than 72 hrs. of age.

By using the blood culture as the gold standard method sensitivity, specificity were calculated for haematological parameters, CRP and procalcitonin.

Total WBC count was abnormal in 6 cases, 4 in proven sepsis and 2 in clinical sepsis group. The sensitivity, specificity of total WBC count were 18.18\%, $92.8 \%$ respectively.

I/T Ratio was increased in 14 neonates, 8 in proven sepsis group, 2 in suspected sepsis group and 4 in clinical sepsis group. The sensitivity, specificity of I/T Ratio was $36.36 \%$, $73.33 \%$ respectively.

Out of 50 neonates CRP level was increased in 26 neonates, 14 in proven sepsis group, 8 in suspected sepsis group and 4 in clinical sepsis group. The sensitivity of CRP in detecting sepsis was $63.33 \%$, its specificity was $57.14 \%$.

Blood culture was positive in 22/50 neonates, 20 in early neonatal sepsis and 2 in late neonatal sepsis group. The organisms identified are CONS (10), Klebsiella (6), Enterococci (2), Proteus (2) and E. coli (2).

In the present study, CONS was the commonly (45\%) isolated organism followed by Klebsiella (3\%).

Procalcitonin level was increased in 12 neonates out of 50,8 in proven sepsis and 4 in clinical sepsis i.e. culture negative patients. We do not have positive result of procalcitonin in suspected sepsis group. The sensitivity of procalcitonin was $36.36 \%$ and the specificity was $85.71 \%$.

\begin{tabular}{|c|c|c|}
\hline & Group & Criteria \\
\hline $\begin{array}{c}\text { Group } \\
\text { I }\end{array}$ & $\begin{array}{l}\text { Proven } \\
\text { Sepsis }\end{array}$ & $\begin{array}{l}\text { Clinical signs and symptoms } \\
\text { plus a positive bacterial culture }\end{array}$ \\
\hline $\begin{array}{l}\text { Group } \\
\text { II }\end{array}$ & $\begin{array}{l}\text { Suspected } \\
\text { Sepsis }\end{array}$ & $\begin{array}{l}\text { Clinical signs and symptoms with } \\
\text { negative bacterial culture, but at least } \\
2 \text { positive screening tests (CRP, White } \\
\text { Blood Cell Count, Platelet Count) }\end{array}$ \\
\hline $\begin{array}{c}\text { Group } \\
\text { III }\end{array}$ & $\begin{array}{l}\text { Clinical } \\
\text { Sepsis }\end{array}$ & $\begin{array}{c}\text { Clinical signs and symptoms } \\
\text { with negative bacterial culture } \\
\text { and negative screening test }\end{array}$ \\
\hline
\end{tabular}

\begin{tabular}{|c|c|c|c|c|}
\hline Group & $\begin{array}{c}\text { Abnormal } \\
\text { WBC } \\
\text { Count }\end{array}$ & $\begin{array}{c}\text { IT/ } \\
\text { Ratio }\end{array}$ & $\begin{array}{c}\text { Elevated } \\
\text { CRP }\end{array}$ & $\begin{array}{c}\text { Elevated } \\
\text { Pro- } \\
\text { calcitonin }\end{array}$ \\
\hline $\begin{array}{c}\text { Clinical } \\
\text { Sepsis } \\
(\mathrm{N}=20)\end{array}$ & 2 & 4 & 4 & 4 \\
\hline $\begin{array}{c}\text { Suspected } \\
\text { Sepsis } \\
(\mathrm{N}=8)\end{array}$ & 0 & 2 & 8 & 0 \\
\hline $\begin{array}{c}\text { Proven } \\
\text { Sepsis } \\
(\mathrm{N}=22)\end{array}$ & 4 & 8 & 14 & 8 \\
\hline
\end{tabular}

Table 2. Comparison of Parameters among Sepsis Group

\begin{tabular}{|c|c|c|}
\hline Parameters & $\begin{array}{c}\text { No. of Positive } \\
\text { Cases } \\
\text { Out of 50 }\end{array}$ & $\begin{array}{c}\text { Culture Positive } \\
\text { Out of 22 }\end{array}$ \\
\hline Abnormal WBC Count & 6 & $4(18.18 \%)$ \\
\hline I/T Ratio & 14 & $8(36.36 \%)$ \\
\hline CRP Level & 26 & $14(63.63 \%)$ \\
\hline Procalcitonin & 12 & $8(36.36 \%)$ \\
\hline \multicolumn{2}{|r|}{$\begin{array}{r}\text { Table 3. Comparison of Parameters } \\
\text { among Culture Positive Neonates }\end{array}$} \\
\hline
\end{tabular}

\section{DISCUSSION}

Neonatal sepsis is an invasive bacterial infection. The incidence of culture proven sepsis is approximately $2 / 1000$ live births and from the $7-13 \%$ of neonates who are evaluated for neonatal sepsis only 3 - $8 \%$ have culture proven sepsis. ${ }^{[8]}$ The early signs of sepsis in the newborn are nonspecific and include diminished spontaneous activity, less vigorous sucking, apnoea, bradycardia, temperature instability, respiratory distress, vomiting, diarrhoea, abdominal distention, mottling, hepatomegaly, cyanosis, abnormal Moro reflex, Fontanelle bulging, seizure and jaundice. Rapid diagnosis of neonatal sepsis is problematic, because the first signs of this disease may be minimal and are similar to those of various non-infectious processes.

Neonatal infection is widely classified into early onset and late onset sepsis.[5]

Early onset sepsis is defined as sepsis within $48-72$ hours of births. The main route of infection are vertical transmission from the mother via transplacental or ascending vaginal routes and postnatally from the environment.

Late onset infection in neonates is defined as infection become clinically evident more than $48-72$ hours after birth, and is usually the result of nosocomially acquired organism.

\section{Tests Employed in Diagnosing Sepsis Total WBC Count}

This is the least useful index, because it varies with gestation and post-natal age can be confused by machines and increased in non-infectious condition. [5]

\section{Neutrophil Ratio}

Normal ranges for neonatal ANC are different from those of infants and children. Although both neutropenia and neutrophilia $\left(<5 \times 10^{9} / \mathrm{L}\right.$ or $\left.>20 \times 10^{9} / \mathrm{L}\right)$ respectively have useful predictive power, in neither case the sensitivity and specificity was low.[6] 


\section{I/T Ratio}

The I/T ratio is useful in diagnosing and monitoring the infection. The maximum normal value is 0.16 during the first 24 hours, 0.14 by 48 hours and 0.13 by 60 hours where it remains until 5 days of age. Thereafter, the maximum normal $\mathrm{I} / \mathrm{T}$ ratio is 0.12 until the end of the first month. Several studies have found that an I/T ratio of $\geq 0.2$ is a useful marker in infection.[6] Manroe et al found that toxic granulation in neutrophil in only $11 \%$ of normal infants compared with $63 \%$ of infants with confirmed sepsis.[8]

\section{Platelet Count}

Thrombocytopaenia is a common feature of neonatal sepsis and infection, but may be seen in non-infective condition such as hypoxic-ischaemic encephalopathy, IUGR and Pregnancyinduced Hypertension. [5]

\section{Cytokines \\ TNF and IL-6}

Elevation of plasma TNF- $\alpha$ and IL- 6 concentration in plasma may provide an early indication of sepsis, but levels may also be raised as a result of non-infective inflammation, Hypoxic ischaemic encephalopathy. According to Mehr and Doyle 2000, IL-6 may be a better marker of early onset sepsis than CRP; however, these cytokine assays have not been introduced in research and have not been introduced into routine practice. ${ }^{[9]}$

\section{Serum Granulocyte CSF}

According to Bedford Russell 2009, plasma G-CSF rises in response to infection and inflammation but responses are no more sensitive or specific than CRP measurements and thus should not be relied upon as a marker of infection or inflammation.[10]

\section{Immunological Tests}

Immunological tests like antigen, antibody detection tests, genetic technique are used to rule out immunodeficiency. ${ }^{[5]}$

\section{Acute Phase Reactants C-Reactive Proteins}

CRP level rise after inflammatory mediators such as interleukin-6 stimulate its synthesis in the liver. It is not uncommon for babies with positive blood cultures to have negligible CRP levels at birth, but the CRP rises some 12 hours or more later.

\section{Procalcitonin}

Procalcitonin is the precursor protein of calcitonin and has no hormonal activity. It is 116 amino-acid protein with a molecular mass of $14.5 \mathrm{KD} .{ }^{[11]}$

Procalcitonin is processed to an $\mathrm{N}$ terminal 57 amino-acid peptide and a 21 amino-acid peptide and Catacalcin. Expression of this group of peptide is normally limited to thyroid $\mathrm{C}$ cells and to a small extent to other neuroendocrine cells.[12] During severe systemic inflammation the tissue specific controls of calcitonin related peptides expression breaks down and procalcitonin, CCP-1 are secreted in larger quantity by many tissue including hepatic cells, monocytes and macrophages through induction by bacterial endotoxin. $[13]$
Non-infectious inflammatory stimuli needs to be extremely severe to result in procalcitonin elevations making it more specific markers for more severe infections than most other inflammatory markers.

Procalcitonin becomes detectable within 2 to 4 hours. In the absence of ongoing stimulus, procalcitonin is eliminated with a half-life of 24 to 35 hours. In 1993, Assicot et al[14] were the first to report increased PCT level after severe bacterial infection with a monoclonal immune radiometric assay. Although CRP level is widely used as an indicator of acute infection, increased CRP levels after the beginning of inflammation is slower than in PCT levels. This difference can be attributed to CRP starting to increase 4 to 6 hours later than PCT after the beginning of inflammation and reaching its peak about 36 hours later. Therefore, PCT is known as a useful indicator for diagnosing early onset sepsis in newborn, because it increases earlier within 12 hours of life than CRP or IL 6 levels and it may also be useful for followup examination.[13]

\section{Reference Values}

Adults and Children

Children less than 72 hours

18 to 30 hours

$>/=72$ hours

$$
\begin{aligned}
& </=0.15 \mathrm{ng} / \mathrm{mL} . \\
& <2 \mathrm{ng} / \mathrm{mL} . \\
& </=20 \mathrm{ng} / \mathrm{mL} . \\
& </=0.15 \mathrm{ng} / \mathrm{mL} .
\end{aligned}
$$

In our study, WBC count was abnormal only in 6 culture positive patients. This finding was comparable with that of study conducted by Suchilathangam et al,[14]

In the present study, I/T ratio was increased in 14 out of 22 culture positive neonates which was contrary to the results of Suchilathangam et al, in which they had abnormal I/T ratio only in 2 cases out of 14 culture positive neonates Ali AM et al[15] found and $63.6 \%$ positive for CRP which was comparable with our study. In our study we got a sensitivity of $63.63 \%$, which is the same as that of Ali AM et al.

Jose B et al[16] in their study they evaluated a sensitivity of $73.8 \%$ and specificity of $80.8 \%$ for procalcitonin within 12 $24 \mathrm{hrs}$. of life. They concluded that the serum procalcitonin concentration showed a moderate diagnostic value for the detection of sepsis with better results after $12 \mathrm{hrs}$. of life. In our study, $92 \%$ of neonates had sepsis after 24 hrs. - 48 hrs. of life.

Ho Park et al[13] evaluated the sensitivity and specificity of procalcitonin to be $88.79 \%$ and $52.66 \%$ respectively. Negative predictive value was $98.6 \%$ and they concluded that procalcitonin may not be a sufficiently reliable diagnostic marker of neonatal sepsis compared with CRP, which had a sensitivity of $100 \%$ in their study. They suggested procalcitonin can be used as a diagnostic marker in combination with other tests for the diagnosis of neonatal sepsis.

Ballot et al[17] suggested that the procalcitonin alone was not sufficient to confirm neonatal sepsis, because of its slightly lower sensitivity, specificity and positive predictability.

Blommendahl et al[18] suggested that Procalcitonin was not a better marker than CRP levels, because Procalcitonin was affected by perinatal factors within 48 hrs. of birth. In our study, the sensitivity of procalcitonin was $36.36 \%$ compared to that of CRP which had a sensitivity of $63.63 \%$. Since $92 \%$ of neonates in our group falls in $24-48 \mathrm{hrs}$. of life, 
the low sensitivity can be attributed to the perinatal factors according to Blommendahl et al Loc. Cit. Furthermore, our small sample size limits the usefulness of procalcitonin in this study. According to Chiesa et al, ${ }^{[19]}$ prenatal antibiotic therapy may be associated with false negative Procalcitonin levels in those with early neonatal sepsis.

\section{CONCLUSION}

We conclude that procalcitonin alone could not be an independent test to confirm neonatal sepsis; it should be combined with the other tests to increase the sensitivity, for timely intervention and unnecessary usage of antibiotics. In the present study, we got a higher sensitivity for CRP than procalcitonin. The low sensitivity of procalcitonin can be attributed to the small sample size and may be due to perinatal factors. Taking the sample size into consideration these findings must further be investigated to get a definitive marker for neonatal sepsis.

\section{ACKNOWLEDGEMENT}

We thank Indian Council of Medical Research (ICMR) and the Department of Clinical Biochemistry. Christian Medical College and Hospital, Vellore. We are also grateful to the Department of Paediatrics, Government Vellore Medical College for their consistent support.

\section{REFERENCES}

[1] Nakajima A, Yazawa J, Sugiki D, et al. Clinical utility of procalcitonin as a marker of sepsis: a potential predictor of causative pathogens. Intern Med 2014;53(14):1497-503.

[2] Stoll BJ. Infection of the neonatal infant. In: Kleigman RM, Stanton BF, StGgeme JW, et al. Nelson textbook of paediatrics. 19th edn. Philadelphia: Elsevier / Saunders 2011:629-48.

[3] Jaswal RS, Kaushal RK, Goel A, et al. Role of the Creactive protein in deciding the duration of the antibiotic therapy in neonatal septicaemia. Indian Pediatr 2003:40(9):880-3.

[4] van Rossum AMC, WulKan RW, Oudesluys-Murphy AM. Procalcitonin as an early marker of infection in neonates and children. Lancet Infect Dis 2004;4(10):620-30.

[5] Rennie JM. Rennie and Robertson's text book of neonatology. $5^{\text {th }}$ edn. Churchill Livingstone 2012:1015-24.

[6] Metsvaht T, Pisarev H, Ilmoja ML, et al. Clinical parameters predicting failure of empirical antibacterial therapy in early onset neonatal sepsis, identified by classification and regression tree analysis. BMC Pediatr 2009 Nov 24;9:72.
[7] Zahedpasha Y, Ahmadpour-Kacho M, Hajiahmadi M, et al. Procalcitonin as a marker of neonatal sepsis. Iran J Pediatr 2009;19(2):117-22.

[8] Manroe BL, Weinberg AG, Rosenfeld CR, et al. The neonatal blood count in health and disease. I. Reference values for neutrophilic cells. J Pediatr 1979;95(1):89-98.

[9] Mehr S, Doyle LW. Cytokines as a marker of bacterial sepsis in newborn infants: a review. Pediatr Infect Dis J 2000;19(9):879-87.

[10] Bedford Russell AR. The role of granulocyte colonystimulating factor in augmenting human neonatal neutrophil host defence. MD Thesis, University of London 2009:115-9.

[11] Whicher J, Bienvenu J, Monneret G. Procalcitonin as an acute phase marker. Ann Clin Biochem 2001;38(Pt 5):483-93.

[12] Assicot M, Gendrel D, Carsin H, et al. High serum procalcitonin concentrations in patients with sepsis and infection. Lancet 1993;341(8844):515-8.

[13] Park IH, Lee SH, Yu ST, et al. Serum procalcitonin as a diagnostic marker of neonatal sepsis. Korean J Pediatr 2014;57(10):451-6.

[14] Sucilathangam G, Amuthavalli K, Velvizhi G, et al. Early diagnostic markers for neonatal sepsis: comparing Procalcitonin (PCT) and C-Reactive Protein (CRP). Journal of Clinical and Diagnostic Research 2012;6(4):627-31.

[15] Ali AM, Elkhatib WF, Abdelaziz SS. Procalcitonin versus C-reactive protein in neonatal sepsis. Journal of Immunology and Infectious Diseases 2014;1(1):1-5.

[16] Sastre JBL, Solís DP, Serradilla VR, et al. Evaluation of procalcitonin for diagnosis of neonatal sepsis of vertical transmission. BMC Pediatr 2007;7:9.

[17] Ballot DE, Perovic O, Galpin J, et al. Serum procalcitonin as an early marker of neonatal sepsis. S Afr Med J 2004;94(10):851-4.

[18] Blommendahl J, Janas M, Laine S, et al. Comparison of procalcitonin with CRP and the differential white blood cell count for the diagnosis of culture-proven neonatal sepsis. Scand J Infect Dis 2002;34(8):620-2.

[19] Chiesa C, Panero A, Rossi N, et al. Reliability of procalcitonin concentrations for the diagnosis of sepsis in critically ill neonates. Clin Infect Dis 1998;26(3):664-72. 